(C) 2012

Малиновская И. М., доктор сельскохозяйственных наук ННЦ «Институт земледелия НААН»

\title{
ВЛИЯНИЕ ПОЖАРА НА СОСТОЯНИЕ МИКРОБИОЦЕНОЗА ПОЧВЫ ВОСЫМИ- И ДВАДЦАТИЛЕТНИХ ЗАЛЕЖЕЙ
}

\section{Рецензент - кандидат биологических наук Ю. А. Драч}

\begin{abstract}
Вивчення стану мікробіоченозів постпірогенних $i$ фонових ділянок восьми- і двадиятирічних перелогів показало, щуо механізм впливу пожежі розрізняється через 3 і 14 місяиів після його проходження. Загальні прочеси, щчо відбуваються внаслідок пожежі через 3 місяиі: зниження чисельності мікроорганізмів, їх фізіолого-біохімічної активності, посилення мінералізації сполук вуглецю й азоту, за виключенням тумусу, підвищення фітотоксичності трунту. Через 14 місяиів внаслідок покрамання мінерального живлення фітоценозу знижуються активність розкладання гумусу і фітотоксичність трунту.
\end{abstract}

Ключевые слова: пожар, микробиоченоз, залежь, эколого-трофические группы, минерализация, гумус, фитотоксичность.

Состояние проблемы. Распаханность сельскохозяйственных угодий в Украине составляет в среднем $82 \%$, в некоторых регионах - до $96 \%$. Сверхнормативная распаханность приводит к ухудшению экологической ситуации: усилению эрозионных процессов, заиливанию русел малых рек, засолению прилегающих к ним земель и др. $[1,8]$. Площадь травянистых биогеоценозов в мире составляет 3,4 млрд га, что в 2,0 раза превышает площадь пахотных земель. В Украине, напротив, их площадь в 7,7 раза меньше пашни [1]. Учитывая большую роль травянистих биогеоценозов, постановлением Минагрополитики Украины и Президиума Украинской академии аграрных наук (2000 г.) предлагается вывести из сельскохозяйственного использования 10 млн гектаров малопродуктивных пахотных земель и перевести их частично под леса (2 млн га), а частично - под луга (10 млн га).

Анализ последних публикаций по данной проблеме. Одним из технологических приемов, позволяющих достичь максимального хозяйственного эффекта при восстановлении травянистих биогеоценозов, является сжигание растительних остатков с целью уничтожения возбудителей болезней и вредителей [1]. Одновременно пожары приводят к поступленню в атмосферу значительных количеств оксидов углерода, азота и потере запасов органического вещества екосистем, содержащихся в фитомассе, подстилке и верхних слоях почвы [10]. Число исследований, посвященных влиянию пожара на состояние микробного сообщества, в доступной литературе ограничено [2, 7]. Установлено, что между пирогенной и фоновой делянками существуют различия по интенсивности респирации и соотношению растворенного органического углерода к общему углероду почвы. Важным с теоретической и практической точек зрения является изучение изменений сообщества почвенных микроорганизмов в ходе восстановления фитоценоза постпирогенных участков.

Целью нашого исследования была оценка влияния пирогенного фактора на численность и соотношение микроорганизмов основных эколого-трофических групп, интенсивность и направленность минерализационных процессов в почвах с разным периодом выведения из сельскохозяйственного использования.

Материалы и методы. Исследования проведены в системе локального мониторинга, созданного на базе стационарного опыта лаборатории интенсивных технологий зерновых колосовых культур и кукурузы ННЦ «Институт земледелия НААН», размещенного на территории опытного хозяйства «Чабаны» в КиевоСвятошинском районе Киевской области на правобережье р. Днепр. Исследования проведены на примере серой лесной почвы на территориально близьких участках: 1 и 2 - почва, выведенная из сельскохозяйственного использования в 1987 г. (двадцатилетняя залежь); 3 и 4 - почва, выведенная из сельскохозяйственного использования в 2000 г. (восьмилетняя залежь). Пожар средней интенсивности произошел в начале апреля 2007 г., в результате чего на большей части площади выгорело покрытие из мха, лишайники, подстилка, подрост деревьев. Пожар малой интенсивности (второй) произошел в начале апреля 2008 г., при этом выгорела только подстилка, накопленная за 2007 год.

Численность микроорганизмов основных эко- 


\section{СІЛЬСЬКЕ ГОСПОДАРСТВО. РОСЛИННИЦТВО}

лого-трофических групп оценивали методом посева почвенной суспензии на соответствующие питательные среды [9]. Показатели интенсивности процессов минерализации, вероятность формирования бактериальных колоний (ВФК) и фитотоксические качества почвы определяли в соответствии с описанным ранее [6]. Коэффициент удельной фосфатрастворяющей активности $(\mathrm{Kr})$ определяли на агаризованных средах по разработанному нами методу [3].

Статистическую обработку результатов проводили с использованием современных программ Microsoft Excel.

Результаты исследования. Исследования, проведенные в 2007 г., показали, что спустя 3 месяца после пожара в почве залежей снижается количество микроорганизмов большинства изученных эколого-трофических групп и их физиологическая активность, усиливается интенсивность минерализационных процессов по сравнению с фоновыми делянками [6]. Пожар 2008 года (вследствие его незначительной мощности) практически не повлиял на содержание в почве двадцатилетней залежи аммонификаторов, целюлолитиков, автохтонных микроорганизмов, стрептомицетов и микромицетов, мобилизаторов органофосфатов (табл. 1). При этом существенно снизилось количество азотобактера, нитрифицирующих бактерий, педотрофов и мобилизаторов минеральных фосфатов. В случае последних также снизилась удельная фосфатрастворяющая активность. Таким образом, вследствие двух пожаров в почве многолетней залежи снизилось, прежде всего, количество микроорганизмов, вовлеченных в цикл углерода. Снижение численности микроорганизмов происходит, на наш взгляд, из-за прогревания верхних слоев почвы в процессе пожара, а позднее - вследствие уменьшения густоты растений и уменьшения количества корневых выделений.

С другой стороны, в результате поступления в почву минеральных веществ после пожара увеличивается количество микроорганизмов цикла азота: иммобилизаторов минерального азота, олигонитрофилов, денитрификаторов.

\section{1. Численность микроорганизмов в серой лесной почве двадцатилетней и восьмилетней}

залежей, млн. КОЕ / г абсолютно сухой почвы

\begin{tabular}{|c|c|c|c|c|c|c|c|c|c|c|c|c|c|c|c|c|}
\hline № & Вариант & 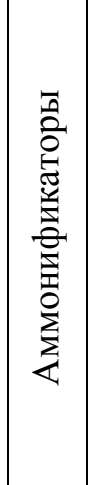 & 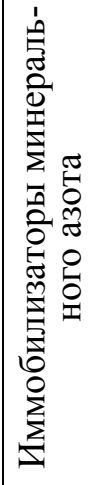 & 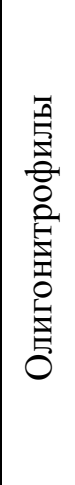 & 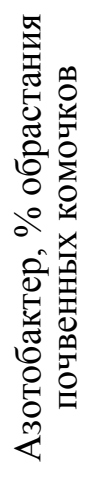 & 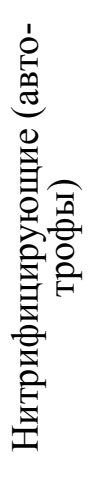 & 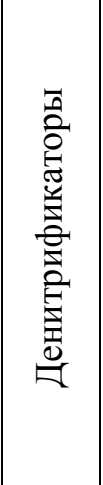 & 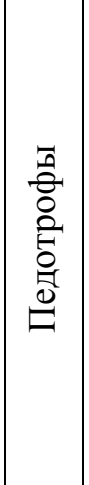 & 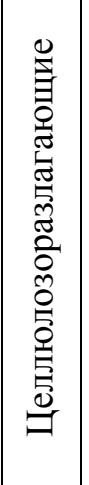 & 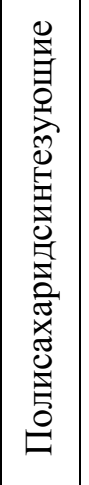 & 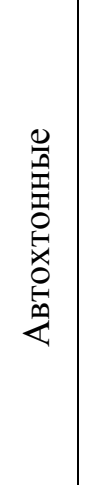 & 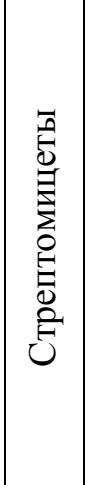 & 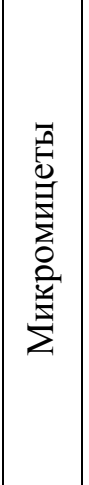 & 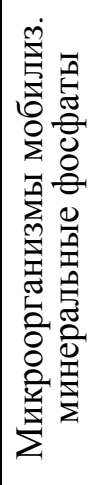 & $\mathrm{Kr}$ & 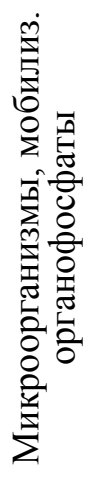 \\
\hline 1 & \begin{tabular}{|c|} 
Двадцатилетняя \\
залежь, пожар \\
в 2007 и 2008 гг. \\
\end{tabular} & $|60,6|$ & 88,5 & 62,8 & 14,7 & 0,64 & 51,2 & 59,6 & 24,7 & $\begin{array}{l}5,12 \\
4,17\end{array}$ & 5,46 & 14,0 & 50,4 & 0,76 & 0,536 & 3,79 \\
\hline 2 & \begin{tabular}{|c|} 
Двадцатилетняя \\
залежь, пожар \\
в 2007 г.
\end{tabular} & 59,0 & 79,5 & 36,7 & 97,0 & 0,87 & 8,51 & 33,3 & $25,0 \mid$ & $|1,14|$ & $5,90 \mid$ & $\mid 12,5$ & 48,4 & 5,62 & 0,601 & 3,03 \\
\hline 3 & $\begin{array}{c}\text { Восьмилетняя } \\
\text { залежь, пожар } \\
\text { в } 2007 \text { г. } \\
\end{array}$ & 59,1 & 101,1 & 25,3 & 2,67 & 0,46 & 122,7 & 58,5 & 33,1 & $|3,35|$. & $3,59 \mid$ & $\mid 15,7$ & 78,8 & 4,09 & 0,417 & 4,46 \\
\hline 4 & \begin{tabular}{|c|} 
Восьмилетняя \\
залежь, фоновый \\
участок
\end{tabular} & 67,8 & 128,7 & 29,2 & 3,01 & 0,49 & 10,6 & 56,0 & 59,0 & 2,98 & 1,96 & 21,3 & $\mid 75,7$ & 4,48 & $0,267 \mid$ & 8,95 \\
\hline & $\mathrm{HIP}_{05}$ & 2,0 & 8,4 & 3,1 & 5,8 & 0,2 & 2,0 & 10,5 & 9,6 & 0,9 & 1,8 & 2,8 & 3,0 & 1,2 & & 0,68 \\
\hline
\end{tabular}

Примечание: * колониеобразующая единица 
Ранее было показано [6], что микроорганизмы почвы, испытавшей влияние пирогенного фактоpa, находятся в менее активном, по сравнению с микроорганизмами фонового участка, физиолого-биохимическом состоянии. Результаты, полученные в 2008 г., подтверждают эту закономерность: физиологическая активность микроорганизмов участка, испытавшего воздействие двух пожаров, ниже активности микроорганизмов участка, испытавшего влияние одного пожара: аммонификаторов - на $56,8 \%$, иммобилизаторов минерального азота - 32,8, педотрофов - 50,0, целлюлолитиков - 26,3, микромицетов - 18,0 , мобилизаторов органофосфатов - 250,0, автохтонных микроорганизмов - на 59,0 \% (табл. 2).

Почва, испытавшая воздействие двух пожаров, характеризуется большей интенсивностью протекания микробиологических процессов по сравнению с почвой, испытавшей воздействие пирогенного фактора только в 2007 году. Это подтверждает общую закономерность, установленную на основании изучения влияния пожара 2007 г., - на постпирогенных участках увеличивается интенсивность минерализации органических (индекс педотрофности) и азотсодержащих веществ (коэффициент минерализации азота) [6].

Несмотря на то, что количество автохтонных микроорганизмов одинаково на участках, испытавших влияние одного и двух пожаров, активность деструкции гумуса ниже на участке, испытавшем влияние двух пожаров (табл. 1, 3). Поскольку на примере пожара 2007 г. было показа- но, что спустя 3 месяца после пожара интенсивность минерализации гумуса остается прежней, то можно предположить, что в 2008 г. проявляется влияние пожара предыдущего года: поступление минеральных элементов с золой снижает активность разложения гумусовых веществ подобно тому, как это наблюдается при внесении минеральных удобрений [4]. Высокий уровень активности минерализации гумуса на участке, испытавшем воздействие одного пожара, совпадает с высокой физиолого-биохимической активностью автохтонных микроорганизмов в почве этого варианта (табл. 2, 3).

Токсичность почвы многолетней залежи на участке, испытавшем влияние двух пожаров, на $12,2 \%$ ниже, чем токсичность почвы участка, испытавшего влияние одного пожара (табл. 3), хотя на примере пожара 2007 г. было показано, что спустя 3 месяца после пожара токсичность почвы постпирогенного участка была на $10,1 \%$ выше токсичности почвы фонового участка [5]. Причиной снижения токсичности почвы на участке, испытавшем влияние двух пожаров, может быть улучшение минерального питания растений спустя 14 месяцев после первого пожара. В данном случае имеет место наложение отрицательного действия второго пожара и положительных последствий первого пожара. Улучшение же минерального питания фитоценоза вследствие различных причин, в частности, внесения минеральных удобрений, приводит к снижению токсичности почвы [4].

\section{2. Вероятность формирования колоний микроорганизмов $\left(\lambda, 4 а c^{-1 .} 10^{-1}\right)$ в серой лесной почве} двадцатилетней и восьмилетней залежей

\begin{tabular}{|c|c|c|c|c|c|c|c|c|c|c|c|c|}
\hline № & Вариант & 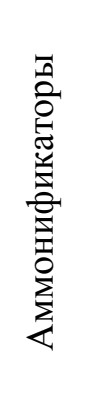 & 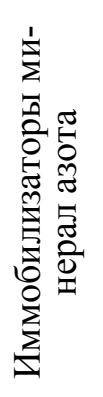 & 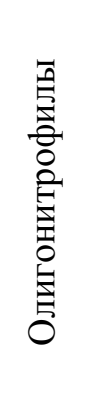 & 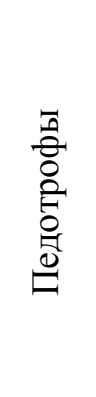 & 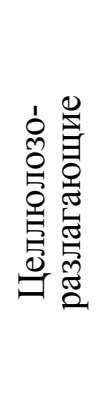 & 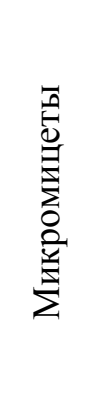 & 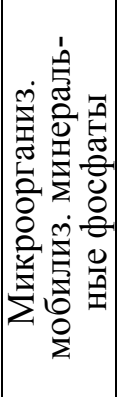 & 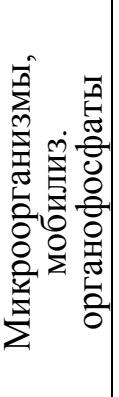 & 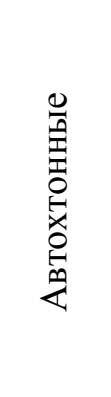 & 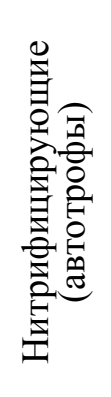 & 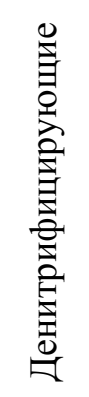 \\
\hline 1 & $\begin{array}{c}\text { Двадцатилетняя } \\
\text { залежь, пожар } \\
\text { в } 2007 \text { и } 2008 \text { гг. }\end{array}$ & 0,88 & 0,67 & 0,35 & 0,52 & 0,19 & 0,39 & 0,08 & 0,08 & 0,039 & 0,051 & 0,34 \\
\hline 2 & \begin{tabular}{|} 
Двадцатилетняя за- \\
лежь, пожар в 2007 г.
\end{tabular} & 1,38 & 0,89 & 0,36 & 0,78 & 0,24 & 0,46 & 0,06 & 0,28 & 0,062 & 0,053 & 0,01 \\
\hline 3 & \begin{tabular}{|c|} 
Восьмилетняя за- \\
лежь, пожар в 2007 г.
\end{tabular} & 0,58 & 0,43 & 0,38 & 0,63 & 0,28 & 0,37 & 0,14 & 0,35 & 0,113 & 0,055 & 0,04 \\
\hline 4 & $\begin{array}{c}\text { Восьмилетняя } \\
\text { залежь, фоновый } \\
\text { участок }\end{array}$ & 0,63 & 0,78 & 0,35 & 0,68 & 0,42 & 0,47 & 0,12 & 0,32 & 0,074 & 0,115 & 0,03 \\
\hline
\end{tabular}


3. Показатели интенсивности минерализационых процессов и фитотоксичность серой лесной почвы двадцатилетней и восьмилетней залежей

\begin{tabular}{|c|c|c|c|c|c|c|c|c|}
\hline \multirow[b]{2}{*}{ № } & \multirow[b]{2}{*}{ Вариант } & \multirow{2}{*}{$\begin{array}{c}\text { Индекс } \\
\text { педо- } \\
\text { троф- } \\
\text { ности }\end{array}$} & \multirow{2}{*}{$\begin{array}{c}\text { Коэффи- } \\
\text { циент } \\
\text { олиго- } \\
\text { трофно- } \\
\text { сти }\end{array}$} & \multirow{2}{*}{$\begin{array}{c}\text { Коэффи- } \\
\text { циент } \\
\text { иммоби- } \\
\text { лизации } \\
\text { азота }\end{array}$} & \multirow{2}{*}{$\begin{array}{c}\text { Активность } \\
\text { минерали- } \\
\text { зации } \\
\text { гумуса, \% }\end{array}$} & \multicolumn{3}{|c|}{$\begin{array}{c}\text { Масса } 100 \text { растений тест- } \\
\text { культуры - пшеницы озимой, г }\end{array}$} \\
\hline & & & & & & стебли & корни & общая масса \\
\hline 1 & $\begin{array}{c}\text { Двадцатилетняя } \\
\text { залежь, пожар в } \\
2007 \text { и } 2008 \text { гг. }\end{array}$ & 0,98 & 1,04 & 1,46 & 9,20 & 9,62 & 10,7 & 20,3 \\
\hline 2 & $\begin{array}{c}\text { Двадцатилетняя } \\
\text { залежь, пожар } \\
\text { в } 2007 \text { г. }\end{array}$ & 0,56 & 0,62 & 1,35 & 17,7 & 8,62 & 9,43 & 18,1 \\
\hline 3 & $\begin{array}{c}\text { Восьмилетняя } \\
\text { залежь, пожар } \\
\text { в } 2007 \text { г. } \\
\end{array}$ & 0,99 & 0,43 & 1,71 & 6,13 & 8,74 & 7,49 & 16,2 \\
\hline 4 & $\begin{array}{c}\text { Восьмилетняя } \\
\text { залежь, фоновый } \\
\text { участок }\end{array}$ & 0,83 & 0,43 & 1,90 & 3,50 & 9,34 & 9,46 & 18,8 \\
\hline & $\mathrm{HIP}_{05}$ & & & & & 0,09 & 0,07 & 0,15 \\
\hline
\end{tabular}

Проведенными ранее исследованиями было показано, что пожар приводит к исчезновению азотобактера из почвы многолетней залежи на протяжении минимум трех месяцев [6]. Спустя год после пожара количество азотобактера в почве многолетней залежи восстанавливается до прежнего уровня $(97 \%)$. Пожар 2008 года тормозит восстановление численности азотобактера, но не так существенно, как в результате предыдущего пожара, который привел к исчезновению этого микроорганизма. Причиной может быть бо́льшая мощность пожара 2007 г. - горела подстилка, накопленная за предыдущие 20 лет, а в 2008 г. - подстилка, накоплення только за один год.

Почва восьмилетней залежи и ранее характеризовалась незначительным содержанием азотобактера; пожар 2007 года также, как и для многолетней залежи, привел к его исчезновению; через год его численность достигла 87 \% исходного уровня (табл. 1).

В почве восьмилетней залежи через 14 месяцев после пожара все еще снижено количество иммобилизаторов минерального азота - на $27,4 \%$, олигонитрофилов - 16 , азотобактера - 13 , целлюлозоразлагающих - 79, стрептомицетов - 36 , мобилизаторов органофосфатов - на $101 \%$ (табл. 1). Микроорганизмы постпирогенного участка этой залежи так же, как и через 3 месяца после пожа$\mathrm{pa}$, характеризуються меньшей физиологической активностью, чем микроорганизмы фоновой делянки. Максимальным различием физиолого- биохимической активности характеризуються иммобилизаторы минерального азота, целлюлозоразлагающие бактерии и нитрификаторы.

По интенсивности расходования органического вещества и гумуса почва постпирогенного участка восьмилетнего перелога превышает показатели фонового участка, однако, в отличие от наблюдений, проведенных спустя 3 месяца после пожара на двадцатилетней залежи, интенсивность процесса оподзаливания выравнивается на этих участках, а процесс минерализации азота становится менее напряженным. Последствия пожара 2007 г. все еще сказываются на фитотоксичности почвы восьмилетней залежи: она выше токсичности почвы фоновой делянки на $16 \%$.

Таким образом, пожары приводят к снижению численности и физиолого-биохимической активности микроорганизмов основных экологотрофических и функциональных групп почв залежей, это снижение имеет место спустя 3 и 14 месяцев после пожара. Амплитуда колебаний этих показателей зависит от группы микроорганизмов и возраста залежи.

\section{Выводы:}

1. Механизм влияния пожара на почвенный микробиоценоз восьмилетней и двадцатилетней залежей отличается через 3 и 14 месяцев после его прохождения. Последствием пожара спустя 3 месяца является снижение численности микроорганизмов всех изученных экологотрофических групп. Спустя 14 месяцев вследствие улучшения минерального питания фитоце- 
ноза численность отдельных групп снижается, а других (в основном, цикла азота) повышается.

2. Физиологическая активность микроорганизмов участков, испытавших воздействие одного и двух пожаров, ниже активности микроорганизмов фонового участка.

3. Токсичность почвы многолетней залежи на участке, испытавшем влияние двух пожаров, на 12,2 \% ниже токсичности почвы участка, испытавшего влияние одного пожара.

\section{БИБЛИОГРАФИЯ}

1. Боговін A. В. Трав'янисті біогеоценози, їхнє поліпшення та раціональне використання / А. В. Боговін, І. Т. Слюсар, М. К. Царенко - К.: Аграрна наука, 2005. - 360с.

2. Ильичев Ю. Н. Лесовозобновление на разных элементах рельефа сосновых гарей / Ю. Н. Ильичев, Н. Т. Бушков, А. А. Полищук // Проблемы лесоводства и лесовосстановления на Алтае. Барнаул. - 2001. - С. 20-22.

3. Малиновская И. М. Определение фосфатрастворяющей активности микроорганизмов на жидкой и агаризованных средах Муромцева / И. М. Малиновская // Агроекологічний журн. - 2002. - №3. C. $68-71$.

4. Малиновська I. М. Особливості мікробних комплексів сірого лісового грунту перелогів та агроценозів / I. М. Малиновська, О. О. Черниш, О. П. Романчук // Зб. наук. праць Інституту землеробства. - К.: Нора Прінт. - 2007. - Вип. 2. C. 29-34.

5. Малиновська I. M. Вплив типу фітоценозу на спрямованість та інтенсивність мікробіологічних процесів у грунті багаторічного перелогу /
4. Почва, испытавшая воздействие двух пожаров, характеризуется большей интенсивностью протекания микробиологических процессов по сравнению с почвой, испытавшей воздействие одного пожара. В ней усиливается интенсивность минерализации органических (индекс педотрофности) и азотсодержащих веществ (коэффициент минерализации азота). Одновременно (вследствие улучшения минерального питания фитоценоза) снижается активность разложения гумуса.

I. М. Малиновська // Вісник Прикарпатського націон. ун-ту: серія Біологія. - 2008. - Вип. 11. C. $68-75$.

6. Малиновська I. М. Стан мікробіоценозів постпірогенної і фонової ділянок сірого лісового грунту / І. М. Малиновська, О. П. Сорока // Зб. наук. праць Інституту землеробства. - К.: ЕКМО, 2008. - Вип. 3-4. - С. 46-51.

7. Наумова Н. Б. Биомасса и активность почвенных микроорганизмов после низового пожара в сосновом лесу / Н. Б. Наумова // Почвоведение. 2005. - №8. - С. 984-987.

8. Сайко В. Ф. Стан земельних угідь та поліпшення їх використання / В. Ф. Сайко // Зб. наук. праць Інституту землеробства. - К.: ЕКМО, 2005. - C. 3-11.

9. Tennep E. 3. Практикум по микробиологии / Е. 3. Теппер, В. К. Шильникова, Г. И. Переверзева. - М.: Дрофа, 2004. - 256 с.

10. Caldwell T. G. Forest floor carbon and nitrogen losses due to prescription fire / T. G. Caldwell, D. W. Johnson, W. W. Miller, R. G. Qualls // Soil Sci. Soc. Am. J. - 2008. - V. 66. - \# 1. - P. 262-267. 